Vol. 3, No. 1, 2016

UDC 378.332

V. V. Voytsekhovska

$\mathrm{PhD}$ of Economic Sciences, Associate Professor

Lviv Polytechnic National University

O. Butzbach

Doctor of Economics, Professor

Seconda Università degli studi di Napoli

\title{
THE ENVIRONMENTAL SUSTAINABILITY - ASSESSMENT OF REGIONAL PRIORITIES FOR AIR POLLUTION REDUCTION
}

\begin{abstract}
The problem of reducing air pollution as key element of environmental sustainability by regional criteria was considered. The basic study approach is taken, according to which the quantitative analysis methods were used to define the relation between air pollution reduction and the relative reduction volume of its negative impact on the region's inhabitants. The result proved that the product of two indicators - the concentration of air pollution and population density in the territory determines the priority of reducing pollution and as a result the implementation of regional eco investments. Conducted interpretation proposed approach using statistical data on air pollution for the largest cities in Italy and dust pollution areas for Polish Voivodships. Corresponding conclusions of practical significance and prospects of the proposed approach to the definition of regional priorities of reducing air pollution were made.
\end{abstract}

Key words: environmental sustainability, regional development, air pollution reduction.

\section{Problem statement}

The problem of sustainability can be seen in global terms, in relation to the continents, regions, countries, localities, sectors of the economy, human settlements, a separate business entities. However in its entirety, this category is only correlated with the entire human civilization. Sustainable development of each country is possible only in the context of sustainable development of the entire human civilization. The same applies to all industries and the settlement of the territorial subsystems of each country. They can only grow steadily as the structural units (branch, territorial, settlement) steadily developing country. One of the major challenges of today's World is to ensure that countries build on the momentum created by the Sustainable Development Summit of the United Nations and truly undertake to adapt the 2030 Agenda to their national situations by reviewing policies, plans and institutions. The countries acknowledged that the Agenda extends beyond development cooperation and are considering relevant reforms in their domestic policies to address its provisions.

The analysis of recent researches and publications

Different authors put different values in this concept, but its genesis in relation to social development as a whole, of course, related to the problem of environmental degradation $[4,6,10]$. The Sustainable development is interpreted as "development that meets the needs of the present, but does not compromise the ability of future generations to meet their own needs". Daly H. E. elaborates on this definition, directly linking the satisfaction of human needs with the use of the biosphere. Leitmann J., Bartone C., define sustainable development as development "where the impact on the environment remains within the economic capacity of the biosphere, so it does not break the natural basis for the reproduction of human life" [10]. This specification is of great practical importance, since hypothetically people can meet their needs, living in tech world.

During the UN General Assembly the importance of environmental component of Sustainable Development was stressed, that economic growth must be decoupled from environmental degradation and combat climate change to protect future generations. The Global Sustainable Development Report by United Nations highlights the importance that no one is left behind is a fundamental guiding principle for the implementation of the 2030 Agenda for Sustainable Development. Science can inform decision-making on three broad questions. First, who are those being or at risk of 


\section{V. Voytsekhovska, O. Butzbach}

being left behind? Second, how can strategies and policies reach them in practice? And third, what types of strategies and policies would be appropriate in order to leave no one behind? [1].

\section{Research objective}

The aim of the study was to determine the priorities of reducing air pollution in some areas. At the same time to put forward the idea that in addition to pollution concentration, the significant role played also the population density living in that area. To realize the goal of the task was to identify and use quantitative methods to describe the relation of pollution to the impact on people with incomplete information regarding this relation. To interpret the results the statistical information available was used for the cities of Italy and Poland Voivodships.

\section{The main results of the research}

The one of the important issues is to assess the negative impact of pollution on the person, such as urban and suburban air. The result may be negative impacts on well-being, health, the number of unproductive days, life expectancy and more. In general, to obtain relevant quantitative relations in this area is very challenging. At the same time focus on some of the features of these peculiarities makes it possible to obtain results that are of practical importance. Thus, air pollution is both an environmental and a social problem, as it leads to a multitude of adverse effects on human health, ecosystems, the built environment and the climate.

Alternatively, in a quantitative form we offer parabolic dependence of the second order, which connects the effect of concentration of harmful components in the air with the effect for humans. By such dependence the relation, that defines pollution emission and its effect is determined:

$$
\Delta E=c d v \Delta Z,
$$

where $\Delta E$ - the change (increase) of effect; $\Delta Z$ the change (increase) of polluting emissions; $d-$ concentration of harmful components at the time of pollution's variation; $v$ - population density, which is constant; $c$ - constant.

From the given dependence follows that the effectiveness of reducing pollution is caused by two parameters - the concentration of harmful component and density of inhabitants in the territory contaminated. At the same level of pollution, its reduction is more important for areas with higher population density. Also unavoidable conclusion that in the absence of pollution or in deserted areas to reduce pollution brings effect within defined criteria. This product determines the priority of measures to reduce pollution [15].

For example, the replacement of vehicles that use liquid fuel to electric is advisable to carry out first in densely populated cities with high air pollution. The same applies to restrictions on the movement of vehicles above-gas emissions [3].

It should be noted that the relation (1) can be used in two ways. The first area - the definition of priority areas to reduce pollution. The second direction - determination or distribution of the funds that would ensure overall maximum benefit from environmental investments.

In this direction, we conducted the relevant calculations involving some statistics from Italy and Poland. It should be noted that the relation (1) can be used for a wide range of objects continents, countries, regions, cities and more. The corresponding analysis was conducted for the largest cities in Italy. In addition to publicly available information on the city's area and the number of residents we used data on air pollution are taken from the report of EEA [5]. Over the last few decades, evidence has been established about a broad range of air pollution's adverse effects on health. These effects are associated with short- and long-term exposure to levels usually experienced by urban populations throughout the world.

The present analysis indicates that air quality policies have delivered many improvements. However, the high amount of population in Europe is still exposed to exceedance of European environmental standards. Average levels of particulate matter of $10 \mu \mathrm{m}^{3}$ or less (PM10) in Italian cities in 2002-2004 ranged from 26,3 to $61,1 \mathrm{mg} / \mathrm{m}^{3}$, with benchmark set by WHO $50 \mathrm{mg} / \mathrm{m}^{3}$. The health impact of air pollution is large: 8220 deaths a year, on average, are attributable to PM10 concentrations above $20 \mathrm{mg} / \mathrm{m}^{3}$. This corresponds to $9 \%$ of the mortality for all causes (excluding accidents) in the population over 30 years of age. The impact on short-term mortality is 1372 deaths, or $1,5 \%$ of the total mortality in the whole population. Hospital admissions attributable to PM10 are of a similar magnitude [7, 14].

The primary data concerning the territory, largest Italian cities population shown in Table 1. 
Table 1 concentration of pollution on population density.

The statistical data concerning population parameters and area of biggest Italian cities, 2014 [2]

\begin{tabular}{|c|l|c|c|c|}
\hline $\mathrm{Nr}$ & City & $\begin{array}{c}\text { Population, } \\
\text { th., ppl. }\end{array}$ & $\begin{array}{c}\text { Area, } \\
\mathrm{km}^{2}\end{array}$ & $\begin{array}{c}\text { Population } \\
\text { density, } \\
\text { th/ } \mathrm{km}^{2}\end{array}$ \\
\hline 1 & Turin & 870,7 & 130,2 & 6,6 \\
\hline 2 & Genoa & 586,7 & 240,3 & 2,4 \\
\hline 3 & Milan & 1337,0 & 181,7 & 7,35 \\
\hline 4 & Bologna & 375,9 & 140,7 & 2,7 \\
\hline 5 & Florence & 361,6 & 102,4 & 3,5 \\
\hline 6 & Rome & 2627,0 & 1285,0 & 2,1 \\
\hline 7 & Naples & 960,0 & 35,5 & 8,2 \\
\hline
\end{tabular}
Istat 2015

Elaborated on data of Annuario statistic italiano,

From these data it follows that the population density is the smallest in Rome and largest in Naples and has a nearly 4 times difference. Such fluctuations significantly influence the effect of changing in pollution, including when it is decreasing. It should be noted that in Rome except permanent residents the tourists should be considered also. But since their stay is temporary, the damage from pollution should be considered with the regard to permanent residents only.

For the priority in air pollution reduction the following data will be used, concerning PM10 [5].

\section{The definition of City's rating for reducing dust pollution}

\begin{tabular}{|c|c|c|c|c|c|}
\hline $\mathrm{Nr}$ & City & $\begin{array}{l}\text { PM } 10 \\
\mu \mathrm{g} / \mathrm{m}^{3}\end{array}$ & 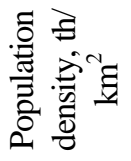 & $\begin{array}{l}\text { Indicator, } \\
\qquad \mathrm{dv}\end{array}$ & 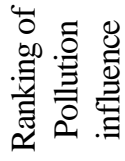 \\
\hline 1 & Turin & 81,0 & 6,6 & 534,6 & 2 \\
\hline 2 & Genoa & 44,6 & 2,4 & 107,0 & 7 \\
\hline 3 & Milan & 66,7 & 7,35 & 490,4 & 3 \\
\hline 4 & Bologna & 57,0 & 2,7 & 153,9 & 5 \\
\hline 5 & Florence & 52,0 & 3,5 & 182,0 & 4 \\
\hline 6 & Rome & 58,0 & 2,1 & 121,8 & 6 \\
\hline 7 & Naples & 75,6 & 8,2 & 619,9 & 1 \\
\hline
\end{tabular}

Elaborated on data of European Environmental Agency, 2015

As seen from the table data the most polluted air is in Turin and the least in Genoa and at least 1.8 times differ. Since, as noted, the population density is significantly different, therefore we note the fluctuating rate criterion - the product of the
The highest priority according to our research is to reduce pollution in Naples where population density is greatest. On the second place is Turin, where the population density is average but most concentrated is air pollution. The main conclusion, according to the proposed approach is to give the priority for pollution reduction is that the population density in the territory, which is also one of the key parameters that can change the option setting priorities as for air pollution.

It should be noted, that we used the statistical results developed by studies of WHO (World Health Organization) and EEA (European Environmental Agency) on the largest cities in Italy. According to these studies the particular matter pollutant (PM 10) is one of the most harmful and leads to many deaths from respiratory and cardiovascular diseases caused by this factor $[5,8]$.

Table 3

The statistical data concerning population parameters, area and amount of dust pollutants emission, Polish Voivodships, 2014 [13]

\begin{tabular}{|c|l|c|c|c|}
\hline $\mathrm{Nr}$ & Voivodships & $\begin{array}{c}\text { Population, } \\
\text { mln., ppl. }\end{array}$ & $\begin{array}{c}\text { Area, in } \\
\text { thousand, } \\
\mathrm{km}^{2}\end{array}$ & $\begin{array}{c}\text { Particulate } \\
\text { dust } \\
\text { pollutants } \\
\text { emission, } \\
\text { in th. ton. }\end{array}$ \\
\hline 1 & $\begin{array}{l}\text { Lower } \\
\text { Silesian }\end{array}$ & 2,9 & 19,9 & 4,0 \\
\hline 2 & $\begin{array}{l}\text { Kuyavian- } \\
\text { Pomeranian }\end{array}$ & 2,1 & 18,0 & 3,9 \\
\hline 3 & Lublin & 2,2 & 25,1 & 2,1 \\
\hline 4 & Lubusz & 1,0 & 14,0 & 1,2 \\
\hline 5 & Lódź & 2,5 & 18,2 & 3,4 \\
\hline 6 & $\begin{array}{l}\text { Lesser } \\
\text { Poland }\end{array}$ & 3,3 & 15,2 & 3,9 \\
\hline 7 & Masovian & 5,3 & 35,5 & 4,6 \\
\hline 8 & Opole & 1,0 & 9,4 & 2,1 \\
\hline 9 & $\begin{array}{l}\text { Subcarpa- } \\
\text { thian }\end{array}$ & 2,1 & 17,8 & 1,7 \\
\hline 10 & Podlaskie & 1,2 & 20,2 & 0,9 \\
\hline 11 & Pomeranian & 2,3 & 18,3 & 2,8 \\
\hline 12 & Silesian & 4,6 & 12,3 & 10,6 \\
\hline 13 & $\begin{array}{l}\text { Święto- } \\
\text { krzyskie }\end{array}$ & 1,3 & 11,7 & 2,7 \\
\hline 14 & $\begin{array}{l}\text { Warmian- } \\
\text { Masurian }\end{array}$ & 1,4 & 24,2 & 1,2 \\
\hline 15 & $\begin{array}{l}\text { Greater } \\
\text { Poland }\end{array}$ & 3,5 & 29,8 & 4,6 \\
\hline 16 & $\begin{array}{l}\text { West } \\
\text { Pomeranian }\end{array}$ & 1,7 & 22,9 & 2,6 \\
\hline
\end{tabular}

Elaborated on data of Statistical Yearbook of Republic of Poland, 2014 


\section{V. Voytsekhovska, O. Butzbach}

For Voivodships of Poland the atmospheric dust pollution was analyzed. The peculiarity of information support of the study was that instead of the value of contamination by volume of the atmosphere considered as analogue ratio reductions in tonnes to fit in Voivodship areas.

Lets take a regional interpretation of equation as an example the emission of dust pollution on the territory of Poland's Voivodships. Relevant primary statistics are given below in Table 1 [13].

Primary data on the absolute area, population, Voivodships pollution are further used to determine the desired relative parameters (Table 4). The results of the corresponding calculations are presented in Table 4 [13].

Table 4

\section{The definition of Voivodeship's rating} for reducing dust pollution

\begin{tabular}{|c|c|c|c|c|c|}
\hline $\mathrm{Nr}$ & Voivodships & $\begin{array}{l}\text { Population } \\
\text { density, } \\
\text { mln., ppl./ } \\
\text { th. } \mathrm{km}^{2} \text {, v }\end{array}$ & $\begin{array}{l}\text { Pollution } \\
\text { concentrati } \\
\text { on, th. ton/ } \\
\text { th.km², v }\end{array}$ & 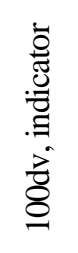 & 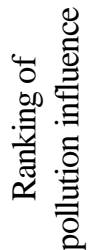 \\
\hline 1 & $\begin{array}{l}\text { Lower } \\
\text { Silesian }\end{array}$ & 0,15 & 0,20 & 3,0 & 3 \\
\hline 2 & $\begin{array}{l}\text { Kuyavian- } \\
\text { Pomeranian } \\
\end{array}$ & 0,12 & 0,22 & 2,6 & 5 \\
\hline 3 & Lublin & 0,09 & 0,08 & 0,7 & 13 \\
\hline 4 & Lubusz & 0,07 & 0,09 & 0,6 & 14 \\
\hline 5 & Łódź & 0,14 & 0,19 & 2,7 & 4 \\
\hline 6 & $\begin{array}{l}\text { Lesser } \\
\text { Poland }\end{array}$ & 0,22 & 0,26 & 5,7 & 2 \\
\hline 7 & Masovian & 0,15 & 0,13 & 2,0 & 7 \\
\hline 8 & Opole & 0,11 & 0,13 & 1,4 & 10 \\
\hline 9 & $\begin{array}{l}\text { Subcarpa- } \\
\text { thian }\end{array}$ & 0,12 & 0,10 & 1,2 & 11 \\
\hline 10 & Podlaskie & 0,06 & 0,04 & 0,2 & 16 \\
\hline 11 & Pomeranian & 0,13 & 0,15 & 1,9 & 8 \\
\hline 12 & Silesian & 0,37 & 0,86 & 11,8 & 1 \\
\hline 13 & $\begin{array}{l}\text { Święto- } \\
\text { krzyskie }\end{array}$ & 0,11 & 0,23 & 2,5 & 6 \\
\hline 14 & $\begin{array}{l}\text { Warmian- } \\
\text { Masurian }\end{array}$ & 0,06 & 0,05 & 0,3 & 15 \\
\hline 15 & $\begin{array}{l}\text { Greater } \\
\text { Poland }\end{array}$ & 0,12 & 0,13 & 1,6 & 9 \\
\hline 16 & $\begin{array}{l}\text { West } \\
\text { Pomeranian }\end{array}$ & 0,07 & 0,11 & 0,8 & 12 \\
\hline
\end{tabular}

Elaborated on data of Statistical Yearbook of Republic of Poland and own calculations, 2014
Out of the data it follows that the maximum level of dust pollution is 20 times greater than its minimum value and a maximum density of population than the minimum of 4 times. According grade ranges 40 times.

If we compare the ratings we shall observe, that the top three priority on reducing pollution include the following Voivodships: Silesian, Lesser Poland, Lower Silesian. The results are conditioned by the fact that in these Voivodships have the largest concentration of pollution and population density living in these areas.

The reason for it should be considered as the presence of large scale industrial production, which requires the involvement of a significant number of employees and activities which are based on industry specifics, that are related to pollution.

Priority means that first of all shall be implemented the environmental initiatives in these areas. But the choices of eco-investments significantly affects the readiness of technical and technological solutions. Also important factors include absolute and specific costs, including such factors as capital intensity reduction of pollution [12-14].

As was previously analyzed from the two areas of air quality improvement for dust pollution better results are achieved, which decreased more rapidly.

The statistical data are further used to determine for each of the Voivodship concentration of gas emissions and population density in the area. The result of this analysis can serve as a measure of efficiency (rate) of pollution reduction. At the same time, the analysis shows a statistical relation, that illustrates a dependency of the correlation. In quantitative form, it has the following linear interpretation:

$$
Z=-0,106+1,05 N \text {, }
$$

The graphic interpretation of given correlation can be observed in figure.

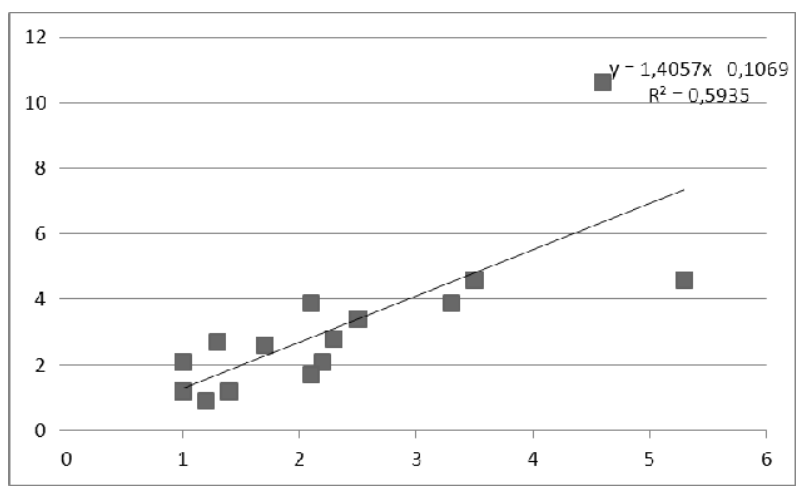

The correlation between dust pollutants (y) and population $(x)$ 
The coefficient of correlation is equal tor $=0,77$. Thus, distresscommunicationis significant.

By dividing the left and right side of the equation on the size of the surface $S$, we obtain the dependence of the concentration of impurities on the density of the population living in the territory:

$$
\frac{Z}{S}=-\frac{0,106}{S}+1,405 N / S \text {. }
$$

General conclusion is that in real business practices the developed pollution type is closely linked to population density in the area. The reason for this phenomenon may be the concentration of production and consequently attract a large number of employees. Concentration in turn leads to an intensification of contamination. Normally the pollution depends on other factors. Selected primary statistics allow to access the problem of prioritization, that reduces pollution by individual region.

Table 5

The calculation's results of the effect of air pollution reduction for the period 2012-2014

\begin{tabular}{|c|l|c|c|c|}
\hline $\mathrm{Nr}$ & Voivodships & $\begin{array}{c}\text { Particulate } \\
\text { dust pollu- } \\
\text { tants emis- } \\
\text { sion, in th. } \\
\text { ton. (2014) }\end{array}$ & $\begin{array}{c}\text { The emission } \\
\text { change: } \\
\text { 2012-2014, } \\
\text { th. ton. } \Delta Z\end{array}$ & $\begin{array}{c}\text { The effect } \\
\text { from the } \\
\text { pollution } \\
\text { reduction } \\
\Delta E^{\prime}=d v \Delta Z\end{array}$ \\
\hline 1 & $\begin{array}{l}\text { Lower } \\
\text { Silesian }\end{array}$ & 3,7 & 0,3 & 0,9 \\
\hline 2 & $\begin{array}{l}\text { Kuyavian- } \\
\text { Pomeranian }\end{array}$ & 3,4 & 0,5 & 1,30 \\
\hline 3 & Lublin & 2,1 & 0,0 & 0,00 \\
\hline 4 & Lubusz & 1,1 & 0,1 & 0,06 \\
\hline 5 & Łódź & 3,2 & 0,2 & 0,54 \\
\hline 6 & $\begin{array}{l}\text { Lesser } \\
\text { Poland }\end{array}$ & 3,6 & 0,3 & 1,71 \\
\hline 7 & Masovian & 4,5 & 0,1 & 0,20 \\
\hline 8 & Opole & 1,9 & 0,2 & 0,48 \\
\hline 9 & $\begin{array}{l}\text { Subcar- } \\
\text { pathian }\end{array}$ & 1,7 & 0,0 & 0,00 \\
\hline 10 & Podlaskie & 0,9 & 0,0 & 0,00 \\
\hline 11 & Pomeranian & 2,4 & 0,4 & 0,76 \\
\hline 12 & Silesian & 10,6 & 0,0 & 0,00 \\
\hline 13 & $\begin{array}{l}\text { Swięto- } \\
\text { krzyskie }\end{array}$ & 2,7 & 0,0 & 0,00 \\
\hline 14 & $\begin{array}{l}\text { Warmian- } \\
\text { Masurian }\end{array}$ & 1,1 & 0,1 & 0,03 \\
\hline 15 & $\begin{array}{l}\text { Greater } \\
\text { Poland }\end{array}$ & 4,5 & 0,1 & 0,18 \\
\hline 16 & $\begin{array}{l}\text { West } \\
\text { Pomeranian }\end{array}$ & 2,6 & 0,0 & 0,00 \\
\hline
\end{tabular}

Elaborated on data of Statistical Yearbook of Republic of Poland
The effect of the priority principle implementation can be determined if we use the equation(1) involving data from two time periods 2012 and 2014 the relevant data and calculations are listed below [12, 13].

According to the statistics the total emission of dust pollution in 2012 amounted to 52,3 th. ton and in 201450 th. ton, which decreased by 2,3 th. tons (by $4,4 \%$ ). The total effect was 6.16 (in relative units). If for example, the money spent on air pollution reduction in the amount of 2,3 th. tons were realized in Silesia, which has the highest priority according to our ranking, the effect would have been an amount equal to 27, 1 (in relative units), therefore more than 4.4 times than actually achieved level. If contamination is reduced to the same extent in Silesia and Malopolska Voivodships, the result would be 3,3 times larger. It can be concluded that prioritizing pollution reduction allows a more rational approach to the allocation costs for that purpose in the general funds in certain areas.

A priori, this can be explained by the fact that there are appropriate technical solutions that do not require for their implementation major capital expenditures. At the same time, the chemical nature of air pollution may require more complex development projects and significant capital investment. Do not forget about the diversification aspects of environmental activities. In the majority of casses, the environmental measures of regions are carried out independently at their own expense and opportunities. A compromise between the interests of the community as a whole and the community in some areas can be achieved through the introduction of appropriate criteria and constraints.

To reduce air pollution it is needed to perform certain research, develop special measures and to invest in ecological projects.

\section{Conclusions}

The developed work have shown, that the choice of parameters, that quantify environmental sustainability should take into consideration the pollution's negative impact at first on the life quality of one man, and then summarize the number of residents living in a particular area.

Taking into consideration air pollution, the output parameters for the performed research, should be considered a harmful gas in the air, the component that is correlated with the amount of gas emissions per unit of area. For residents of the entire territory 


\section{V. Voytsekhovska, O. Butzbach}

the overall pollution impact is considered additive, which will be proportional to the population.

The statistical analysis of largest Italian cities and Polish Voivodship demonstrates, that these indicators and their product significantly differ for different areas - different regions of one country, on given example of Poland and Italy. Therefore, the main dependence can be used to identify priority areas for the implementation of measures in order to reduce air pollution. In order to select appropriate investment projects, we require further assessment of the eco-costs effectiveness, which is largely dependent on the innovation degree of new technology. The strategy to reduce air pollution at the country level should consist the eco-activities for every city, territory, region considering the pollution's degree, the industrial specifics as well as general and local resource capacity allocation, formation and implementation of eco-investment projects.

\section{References}

1. Transforming our world: the 2030 Agenda for Sustainable Development, United Nations Resolution, General Assembly, 25 september 2015.

2. Annuario statistic italiano, Istat, 2015.

3. Benessere equo e sostenibile 2015: principali risultati, Istat, 2015.

4. Daly H. E., 1990. Towards some operational principles of sustainable development. Ecological Economics 2:1-6.
5. European Environment Agency. Air pollutant concentrations at station level (statistics)/November 30, 2015.

6. Jeffrey D. Sachs. The age of sustainable Development/Columbia University Press New York, March 2015, 544 p.

7. Health impact of PM10 and ozone in 13 Italian cities (2006), WHO-Europe.

8. Health risk assessment of air pollution. General principles. WHO, 2016.

9. Istat, Ambiente ed energia, Archivio dei comunicati stampa-[http://www.istat.it/it/ambiente-ed-energia]

10. Leitmann J., Bartone C. et al. (1992). "Environmental management and urban development: issues and options for third world cities." Environment and Urbanization 4(2): 131-140.

11. Rockström, Johan, Jerey D. Sachs, Marcus C. Öhman, and Guido Schmidt-Traub. "Sustainable Development and Planetary Boundaries." Background Paper for the High-Level Panel of Eminent Persons on the Post-Development Agenda. New York: Sustainable Development Solutions Network, 2015

12. Statistical yearbook, Republic of Poland, Voivodships, 2012.

13. Statistical regional yearbook, Republic of Poland, Voivodship Nr: 1-16, 2014.

14. The 2050 vision is set out in the EU's 7th Environment Action Programme (EU, 2013).

15. Voytsekhovskyy V., Voytsekhovska V. Metodological aspects of quantitative assessment of the pollution reduction status and trend // MEST Journal Vol. 3, No. 1, pp. 163-169. 